\title{
Displacement and Narrative: The Desert as a Diasporic Space of Existence in the Goat Days by Benyamin
}

Mariam John

Assistant Professor

St Cyril's College

Adoor, Kerala, India

mariamjohn21@gmail.com

\begin{abstract}
Emerson in his essay 'Experience' brings forth the idea of the cosmological relation between the universe and the human being. What we perceive as truth is not the reality because it exists in space and it is not an absolute entity. But Life - from minute particles, sub atoms, plants, animals, humans - creates the environment and the universe. Universe is the complete spatio temporal logic of the individual self. Thus from the mist to man-made things we try to understand and give meaning to ourselves and to the world around us.
\end{abstract}

Introduction

The place of exile is often regarded as a desert- an unfriendly, hostile, dry, dangerous, empty, naked, rough and endless landscape. The desert as a metaphor is often described as a landmark that can never be mapped and where nothing grows. It is a space of unparallel lives and meaningless values. Benyamin's Goat days analyses the desert as a space of asserting faith, brotherhood and love for humanity at large. Najeeb, narrator and protagonist of the novel calls his life in the desert "a cocooned existence" (135), a lonely being with no sense of time. The 
novel can be rightly called "a desert odyssey" (201). Najeeb says that the desert never gave him any kind of spiritual enlightenment but looking at the novel closely one can find that his life in the desert is a kind of spiritual lesson of faith and perseverance. It is a journey of understanding, motivation and creating self-consciousness. Thus Najeeb's life narrative is a desert odyssey of will, strength and prayer. It purgates the reader's soul with questions of existence, fate, destiny and God. So, truly this desert saga has a spiritual significance.

Transnationalism and Migration

Globalization has marked an existence of borderless economies between nations losing the significance of nations and nationalities; instead creating nation-states. Thus, it is only through globalization that one can reach transnationalism. Transnationalism as an abstract term has been in vogue from the beginnings of twentieth century. It deals with the understanding of the social fields build by immigrants across the world. Transnationalism as a theory had its first existence in the 1990's. Theoretically, it can be defined as a process "by which immigrants build social fields that link together their country of origin and their country of settlement.'(Glick Schiller 1)

Transnationalism can have intra meanings of having an economic agenda if closely read in lines with globalization but it has a political face too. The global world presents bordercrossings and nations that transcend boundaries for immigrant recruitment but transnationalism exposes the sense of belonging in a diasporic culture. For Patricia Clavin, transnationalism resembles an honeycomb which has a rigid and defined shape while still remaining porous to allow plenty of space for the transnational movement of nongovernmental groups.(438-439) 
The wider range of reading transnationalism can be attributed to the boom of information technology in the 1980's. The cheaper and faster transports and development in information and communication technologies have enabled people to move more easily send money and goods more cheaply and quickly, and maintain personal connections with family and friends. These increasing options for transnational connections have a wide range of implications for the lives of both migrants and those remaining 'at home'. Since emerging in the 1990 s the literature on the transnational practices of migrants has focused primarily on individuals and families: "how ordinary individuals live their everyday lives across borders and the consequences of their activities for sending- and receiving-country life ." (Levitt and Waters 8)

The literature on 'home' reveals the tension between the physical place of home and the symbolic space, and home is seen not only as a territorial attachment but also as an adherence to 'transportable cultural ideas and values'.(Al-Ali and Koser 7) The experience of the migrant changes drastically because of the transnational exposure, he starts thinking differently in terms of family, home and nation. It enlarges novel outlook on issues like identity, space, place, language, religion and family.

Transnationalism can be further distinguished as "transnationalism from above" and “transnationalism from below”.( Guarnizo and Smith 1998) The former refers to cross- border activities conducted by governments and corporations, while the latter encompasses activities of immigrants and grassroots entrepreneurs. Focusing on "transnationalism from below" allows us to capture the local and specific dynamics of power relations in the transnational arena.

In the sphere of transnationalism, there is linkages or multiple memberships either with another nation state or with any other social institution such as religious groups, political organization or families. These linkages are differently named as forms of being and forms of 
belonging which people combine in different ways within transnational social fields. Ways of being refers to the actual social relations and practices that individuals engage in rather than to the identities associated with their actions. They have the potential to act or identify at a particular time because they live within the social field. In contrast, ways of belonging refers to practices that signal or enact an identity which demonstrates a conscious connection to a particular group. These actions are not symbolic but concrete, visible actions that mark belonging, thus combining action and an awareness of identity that action signifies. In other words, the experience of the migrants is simultaneously in the middle; integration within societies of receiving countries while also maintaining a strong link with their places of origin.

Migrant transformations would be incomplete if 'locality' and 'spatiality' (Glick Schiller and Caglar 2008) are not theoretically examined. The studies in migration involve the places of origin and destination as migrants are local actors in both contexts.

Migrants are part of the social fabric of the cities in which they are settling. Migrant ties, activities and practices- in short migrants as forces of integration as well as fragmentation-are parts of the changing urban politics and new geographies of urban governance and representation. (ibid 20)

Migration flows influence the local context structure at local, regional and national levels.

\section{Existence of a Migrant as a 'Goat'}

The Gulf attracted the labour market from continents during the oil boom of the 1970s. Especially migrants from South- Asia were the first beneficiaries of the petro-dollar driven economies. The migration studies extol the 'push -pull' process; that is unfavourable conditions push people out, whereas favourable conditions in an external location pull them in. The theory 
also puts forward the demarcations on the basis of labour. Segmented labour market theory suggests that the developed economies are dualistic; firstly they have a primary market of secure, well-remunerated work and a secondary market of low-wage work. Even the native population discards these jobs because of their poor working conditions-low wages or no wages at all, insecurity, improper accommodation and food, suppression of all kind from beatings to locking your travel documents and not allowing communicating with family. Najeeb when he first landed the sand dunes of Arabia had dreams - "I dreamt a host of dreams. Perhaps the same stock dreams that the 1.4 million malayalis in the Gulf had when they were in Kerala - gold watch, fridge, TV, car, AC, tape recorder, VCP, a heavy gold chain”.( Goat Days 38) But instead ended up in a livestock ranch in the desert with a cruel arabab and a scary figure. He was trapped between the burning sands and freezing nights, wracked by loneliness and finding no way to escape, the narrative provides a stunned response of an immigrant to survive. Najeeb's story is a chilling account of the extreme subjugation of body and mind, a journey into darkness that could easily lead to defeat or self-annihilation but for the existence of that third entity- the spirit.

Najeeb's first response to the job is fear, sorrow, anger and hunger. But later he accepts the life and the surroundings, makes the desert goat farm a 'locality'. He is able to create a structure of feeling, a property of life trying to establish a home. He tries to identify himself with the only other living beings on the ranch except the arabab - camels and goats. Especially with the goats- helping a pregnant goat, naming the new born lamb, caring and sharing with the goats ,even sleeping with them. He gradually “accustomed to an uncommon situation.”(104) Najeeb recalls the secret wish he had when he was a child- that he wanted to become a shepherd; "to saunter with flocks of goats through meadows and hillsides. To pitch one's tent everyday in a 
new place. To sit by the fire guarding goats on winter nights. Shepherding was for me what dreams were made of."(124)

Habitus, a concept forwarded by Pierre Bourdieu's habit and habituation with no learned rules or principles. It refers to socially and culturally set dispositions for action. It is a dual frame of reference through which migrants constantly compare their situation in their 'home' society to their situation in the 'host' society abroad. Najeeb's survival in the desert and with the goats explains his social competency. He was never disillusioned but his immense faith in Allah kept him alive: "the two factors that helped me through that phase (surviving with a swollen hand) were my desire to live and my infinite faith in Allah." Another important thing is his oneness with the goats, conscious acceptance of a being in the masara. He has repeated in his narrative that goats understood him better than the arabab. Goats were the physical extensions of his internal longings for home, his unseen son Nabeel is being identified with a kid and when the arabab mutilates it : "the day Nabeel lost his manliness, I too lost mine.I haven't yet figured out that mystery- of how my virility vanished with that of a goat's!".(115)

Najeeb always retells the fact that he lived a goat's life in the desert. He had eaten their food, slept with them, talked with them; his life was divided among them. His decision to discard mutton from his meals is a turning point in his life. He recounts the desperate incident of a hegoat saving his life from the arabab's gunshot when he tried to escape. Najeeb was beaten after the incident and the goat was roasted in fire, when Najeeb was given a portion of the flesh he declined: 'I felt nauseated, as if I was devouring my own brother's flesh. I couldn't eat any of it. I vomited the little that went in. Since then I have never eaten mutton. I have never felt like having it." (143) For muslims all over the world mutton is one of their traditional dishes, even they have the feast of the lamb commemorating Abraham's sacrifice. Thus Najeeb relates his life 
in the desert with that of a goat: "I remained a goat in the masara of goats. (176) I was one of the goats. Mine was a goat's life. (253)

Desert or Narrative Space of Existence

"Desert! A real Desert! An endless stretch of sand as far as the eye could see in the front and the back, on the right and the left. A sea of undulating sand from horizon to horizon ! There was nothing to hinder my sight. No tree. No plant. No hill. Nothing at all. Nothing ." (199) The narrator when he was in Kerala was a sand diver who chose to spend from dawn to dusk in the river. But when he reaches Riyadh and later to the masara, Najeeb is astounded by the vastness of the desert as he calls it, "a sterile wasteland."(74)

Bruce Chatwin in his book The Songlines a half- fictionalized travelogue says that man was born in the desert, and by returning to the desert he rediscovers himself. the narrator also reinvent himself after walking and understanding the desert. Eventhough we may not see greenery in the desert it is also a hub of life, it has an ecosystem. That is why Najeeb later calls it a forest, swarming with living beings. Travelling is a mode of finding a way home and also understanding the self. Every displaced migrant travels from his home country to his host country. This kind of a displacement gives the migrant a cultural competence of accepting the other life in the diasporas of existence. Najeeb too in the masara develops a kind of responsibility in taking charge of his duty and that's how he survive under the harsh conditions.

Najeeb's account of the winter in the desert propels the optimism of the downtrodden and subjugated other that there is a day for everyone: "Winter was also the time when I learned that it was impossible to wipe out life on this earth whatever man's misdeeds" (144) after months 
of scorching heat in the desert finally when it rains a green carpet is laid on the sand. He also learn a lesson about life:

The realization that those plants and animals had been lying quietly- preserving their lives, withstanding the heat of the desert- filled me with delight.... Those plants taught me life's great lessons of hope. They whispered to me: Najeeb, adopted son of the desert, like us, you too must preserve your life and wrestle with this desert. Hot winds and scorching days will pass. Don't surrender to them. (144-145)

Najeeb's escape from the desert is only because of his patience to wait for the appropriate time. Even he realizes his abode in the masara as a safe place: "Every prison has its own aura of safety. I didn't feel up to bursting that bubble of security." (141) Najeeb's waiting come to an end when a third one came to the midst of Najeeb and Hakim; Ibrahim Khadiri from Somalia. He knew the desert before and agreed to help them to escape from there.

The philosopher Alain de Botton signifies the existence of desert as a space of sublime experience. The sublime is a feeling of powerlessness being aroused in places of extreme natural beauty: deserts, glaciers, mountains and canyons. When one comes in contact with these places one would rather be wonder struck than appreciate the beauty of the place. These spaces of vast voidness illustrate the reality and truth of basic human nature. As de Botton himself puts it rightly; that the universe is mightier than we are, that we are frail and temporary and have no alternative but to accept limitations on our will; that we must bow to necessities greater than ourselves. Our perception and knowledge of knowing this world is minimal when we encounter natural spaces of less survival. Najeeb had to suffer throughout the exodus in the desert, the only consolation is the help and support of Ibrahim Khadiri. Khadiri knows the desert by heart; he can understand the tad changes of the vast ocean of sand. Their escape before the sand wave and his 
lessons on drinking water helped Najeeb to live through the desert odyssey. Thus Khadiri is an epitome of perseverance and the interpreter of nature. The survival of the fittest demands a true nature of succumbing and adjusting to the laws of nature and for that Khadiri was the guide and savior of Najeeb.

Najeeb's life as a migrant and his escape from the torture in a foreign land can be seen as a transnational experience. The multi-local life-world or the transnational social life has a set of conditions in the construction, negotiation and reproduction of social identities. Najeeb's identity of being a shepherd in the desert is positioned well off because of the perceived belonging in the space of attachment. Thus Najeeb's adaptation in the desert is due to his inherent perception of belonging to the space of existence and to attain this he was helped by the goats.

Immanuel Kant's views on space and time discloses the fact that space is not something objective or real instead it is subjective and ideal and originates from the mind's nature, for coordinated everything externally.

\section{Conclusion}

Space does not merely produce a background for cultural arrangements rather it is an integral part of cultural and political processes. This extends beyond 'space' as the bone of contention of territorial struggles, beyond questions of cultural location and beyond spatial metaphors of resistance. The transnational life of Najeeb has been implausible in the sense that, he never had any sort of communication with his family, or his workplace was never a place of economical advantage, nor he had any friends. The life of Najeeb in the Arabab's farm, rather than the slave content of the last century are close to the apperception of a 'new migrant' of this century. 
Bibliography

Barkan Elazar and Marie- Denise Shelton.(eds.) Borders,Exiles, Diasporas. California: Stanford University Press, 1998.

Benyamin. Goat Days. Thrissur: Green Books,2008.

Benyamin. Goat Days. Joseph Koipally (trans.). Navi Mumbai: Penguin,2012.

Clavin, Patricia. Defining Transnationalism. Contemporary European History 14.4 (November 2005): 421-39. Historical Abstracts. Web. 22 May 2012

Helff,Sissy and Frank Schulze-Engler. Transcultural English Studies: Theories, Fictions, Realities. New York: Rodopi, 2009.

Innes, C.L. The Cambridge Introduction To Postcolonial Literatures in English. New York: Cambridge University Press, 2007.

Lee, Helen and Steve Tupai Francis. Migration and Transnationalism-Pacific Perspectives. ANU E Press: Australia, 2009.

Levitt, Peggy and Mary C. Waters. (ed) The Changing Face of Home: The Transnational Lives of the Second Generation. Russell Sage Foundation: United States, 2002.

Shackleton, Mark. (Ed.) Diasporic LiteraryTheory - Where Now?. Cambridge Scholars Publishing: United Kingdom, 2008.

Schiller,N.G.,Basch,L. and Blanc- Szanton,C. Transnationalism: A New Analytic Framework forUnderstanding Migration.Annals of the New York Academy of Sciences,645: 124,1992 .

Schiller, Glick. Nina Basch, Linda and Blanc Szanton. Towards a Transnational Perspective on Migration : Race, Class, Ethinicity and Nationalism Reconsidered. New York: New York Academy of Sciences, 1992. 
SMART MOVES JOURNAL IJELLH $\quad$ e-ISSN: 2582-3574 p-ISSN: 2582-4406 VOL. 8, ISSUE 11, NOVEMBER 2020

Vertovec, Steven. Transnationalism. London and New York: Routledge, 2009. 